\title{
Establishment of a quantitative RT-PCR detection of SARS-CoV-2 virus
}

\author{
Yushen Jiang ${ }^{1 *}$, Shanming Zhang ${ }^{2}$, Hong Qin², Shuai Meng ${ }^{1}$, Xuyi Deng ${ }^{3}$, He Lin ${ }^{4}$, Xiaoliang Xin ${ }^{1}$, Yuxin Liang , \\ Bowen Chen ', Yan Cui ', YiHeng Su', Pei Liang ${ }^{1}$, GuangZhi Zhou ${ }^{5}$ and Hongbo Hu ${ }^{5}$
}

\begin{abstract}
Background: The outbreak of novel coronavirus disease 2019 (COVID-19) has become a public health emergency of international concern. Quantitative testing of SARS-CoV-2 (severe acute respiratory syndrome coronavirus 2) virus is demanded in evaluating the efficacy of antiviral drugs and vaccines and RT-PCR can be widely deployed in the clinical assay of viral loads. Here, we developed a quantitative RT-PCR method for SARS-CoV-2 virus detection in this study.

Methods: RT-PCR kits targeting E (envelope) gene, N (nucleocapsid) gene and RdRP (RNA-dependent RNA polymerase) gene of SARS-CoV-2 from Roche Diagnostics were evaluated and E gene kit was employed for quantitative detection of COVID-19 virus using Cobas Z480. Viral load was calculated according to the standard curve established by series dilution of an E-gene RNA standard provided by Tib-Molbiol (a division of Roche Diagnostics). Assay performance was evaluated.
\end{abstract}

Results: The performance of the assay is acceptable with limit of detection (LOD) below $10 \mathrm{E} 1 \mathrm{copies} / \mu \mathrm{L}$ and lower limit of quantification (LLOQ) as 10E2 copies/ $\mu \mathrm{L}$.

Conclusion: A quantitative detection of the COVID-19 virus based on RT-PCR was established.

Keywords: SARS-CoV-2 virus, COVID-19, RT-PCR, Quantitative, RNA

\section{Introduction}

Facing the emergence of coronavirus disease-2019 (COVID-19) worldwide, dozens of RT-PCR virus detection methods targeting SARS-CoV-2 (severe acute respiratory syndrome coronavirus 2) have been established over the past 6 months while few of them are quantitative methods [1-3]. Some researches displayed that clinical manifestations of other coronavirus lung diseases such as severe acute respiratory syndrome (SARS) were related to viral load $[4,5]$. Many studies have focused on the SARS-CoV-2 viral load in specimens of infected patients, and high viral loads were detected soon after symptom onset [6-8]. Moreover, dozens of clinical trials targeting

*Correspondence: jiang_yushen@163.com

${ }^{1}$ Rapid Diagnostics Laboratory, Hangzhou DIAN Medical Laboratories, No. 329 of Jinpeng Street, Xihu District, Hangzhou 310030, China

Full list of author information is available at the end of the article
SARS-CoV-2 have been run all over the world, viral load determination before and after treatment is critical in evaluating clinical efficacy. Therefore, quantitative testing of the COVID-19 virus is demanded in laboratories worldwide, especially in clinical trials of new treatment. In this study, we developed a quantitative COVID-19 detection method based on the Roche RT-PCR coronavirus $\mathrm{E}$ gene detection kit. Its performance is experimentally confirmed and evaluated, and we also employed it in the virus detection of clinical trials LOTUS China (Lopinavir Trial for Suppression of SARS-Cov-2 in China) [9] and NCT04257656 (Remdesivir Trial for Suppression of SARS-Cov-2 in China) [10].

\section{Materials and methods Method design}

SARS-CoV-2 virus composed of 29,881 bp is a singlestrand RNA virus which is divided into ORF region, $\mathrm{S}$ original author(s) and the source, provide a link to the Creative Commons licence, and indicate if changes were made. The images or other third party material in this article are included in the article's Creative Commons licence, unless indicated otherwise in a credit line to the material. If material is not included in the article's Creative Commons licence and your intended use is not permitted by statutory regulation or exceeds the permitted use, you will need to obtain permission directly from the copyright holder. To view a copy of this licence, visit http://creativecommons.org/licenses/by/4.0/. The Creative Commons Public Domain Dedication waiver (http://creativeco mmons.org/publicdomain/zero/1.0/) applies to the data made available in this article, unless otherwise stated in a credit line to the data. 
gene, $\mathrm{M}$ gene, $\mathrm{E}$ gene and $\mathrm{N}$ gene [11]. This novel coronavirus detection method is based on the qPCR platform of Roche Diagnostics. Specific primers and probes are designed to detect three genes: RNA-dependent RNA polymerase (RdRP), $\mathrm{N}$ gene and $\mathrm{E}$ gene.

RNA-dependent RNA polymerase (RdRP) located at the ORF 1ab region is the specific gene that can identify the SARS-CoV-2 virus from COV NL63, 229E, HKU, OC43 or MERS. A fragment of $100 \mathrm{bp}$ in length is designed to the conserved region of the RdRP gene and detected by a new FAM probe labeled for targeting fragment. SARS-CoV-2 virus, SARS virus and bat virusspecific FAM markers were used to detect the amplified fragment of $126 \mathrm{bp}$ in the $\mathrm{N}$ gene region and $76 \mathrm{bp}$ in the $\mathrm{E}$ gene region. All the primer and probe sequences were designed according to WHO published virus sequence and/or published in the previous paper [10].

Using the E gene region for primary screening of virus infection, the highly conserved $\mathrm{N}$ gene can specifically detect the SARS-CoV-2 virus and some others to confirm SARS infection, the RdRp gene is used to identify SARS-CoV-2 virus with high specificity. Medical records between January 10 and January 20, 2020 showed that a 55-year-old male and his wife presented with fever, cough, and shortness of breath, after short-term exposure to Wuhan Huanan seafood market for 2 days. Patients obtained sputum or endotracheal aspirates at admission for identification of possible causative bacteria or fungi. Additionally, chest X-rays or chest $\mathrm{CT}$ were given and treated in isolation. Patient were given antiviral treatment for 3-14 days, including oseltamivir (75 mg every $12 \mathrm{~h}$, orally), ganciclovir $(0.25 \mathrm{~g}$ every $12 \mathrm{~h}$, intravenously), and lopinavir and ritonavir tablets (500 $\mathrm{mg}$ twice daily, orally). To the best of our knowledge, there are no identified variant of SARS-CoV-2 between the period of January 10 and January 20, 2020. Therefore, only when the $\mathrm{R}$ gene is positive and either $\mathrm{N}$ gene or $\mathrm{E}$ gene is positive could be regarded as SARS-CoV-2 virus-specific infection.

\section{Materials for detection}

RNA was extracted using the MagNA Pure 96 system (Roche, Germany) with the High Pure Viral RNA Kit (Roche, Germany. Product No. 11858882001).

A LightMix ${ }^{\circledR}$ Modular EAV RNA Extraction Control (580) kit (Roche, Germany. Product No. 07654243001) was used for extraction and reverse-transcription PCR control.

EAV is in vitro transcribed RNA and not viral RNA or a virus provided as a virus extraction control. The control is a 70-bp-long fragment from the Equine Arteritis Virus genome, which is amplified with specific primers and detected with an Atto647-labeled hydrolysis probe.
A LightCycler ${ }^{\circledR}$ Multiplex RNA Virus Master kit (Roche, Germany. Product No. 06754155001) one-step real-time reverse-transcription PCR kit was used for reverse-transcription RT-PCR.

The E-gene RNA single positive control (Tib-Molbiol, Germany. Product No. 30743771) contains 10E10 copies of RNA in one vial. The N-gene RNA single positive control (Tib-Molbiol, Germany. Product No. 30743671) contains 10E10 copies of RNA in one vial. The RdRpgene RNA single positive control (Tib-Molbiol, Germany. Product No. 30744071) contains 10E10 copies of RNA in one vial.

LightMix ${ }^{\circledR}$ Modular SARS-CoV (COVID19) E-gene kit (Roche, Germany. Product No. 09155368001), LightMix ${ }^{\circledR}$ Modular SARS-CoV (COVID19) N-gene kit (Roche, Germany. Product No. 09155350001), LightMix ${ }^{\circledR}$ Modular SARS-CoV (COVID19) RdRP-gene kit (Roche, Germany. Product No. 09155376001) based on a previously published assay targeting $\mathrm{E}$ gene (envelope protein gene), $\mathrm{N}$ gene (nucleocapsid protein gene) and RdRP gene (RNAdependent RNA polymerase gene) of coronavirus are employed for use on Roche cobas ${ }^{\circledR}$ Z480 RT-PCR system [12].

\section{Pre-experiment}

The purpose of the pre-experiment was to evaluate and select suitable genes for viral load quantification. The assay was conducted according to the instruction of the kit. The standards for RdRP, N and E genes were prepared freshly for each batch. One tube of storage solution was thawed and dilution rows from 10E6 to $10 \mathrm{E} 1$ copies $/ \mu \mathrm{L}$ were obtained by serial $1: 10$ dilution $(10 \mu \mathrm{L}$ of solution diluted with $90 \mu \mathrm{L}$ of PCR-grade water).

RdRP, $\mathrm{N}$ and E-genes were evaluated using serially diluted standards. Results in Additional file 1: Table S1 showing E-gene was more suitable for quantification after SARS-CoV-2 virus infection is confirmed by RdRPgene and N-gene, as shown in Figs. 1, 2 and 3, and Additional file 1: Table S1.

\section{RT-PCR for COVID-19 virus detection}

LightMix ${ }^{\circledR}$ Modular EAV RNA Extraction Control (580) kit (Roche, Germany. Product No. 07654243001) was used for extraction and reverse-transcription PCR control.

LightCycler ${ }^{\circledR}$ Multiplex RNA Virus Master kit (Roche, Germany. Product No. 06754155001) one-step real-time reverse-transcription PCR kit was used for reverse-transcription RT-PCR.

LightMix ${ }^{\circledR}$ Modular SARS-CoV (COVID19) E-gene kit (Roche, Germany. Product No. 09155368001) based on a previously published assay targeting E gene (envelope protein gene) of coronavirus was employed on Roche 

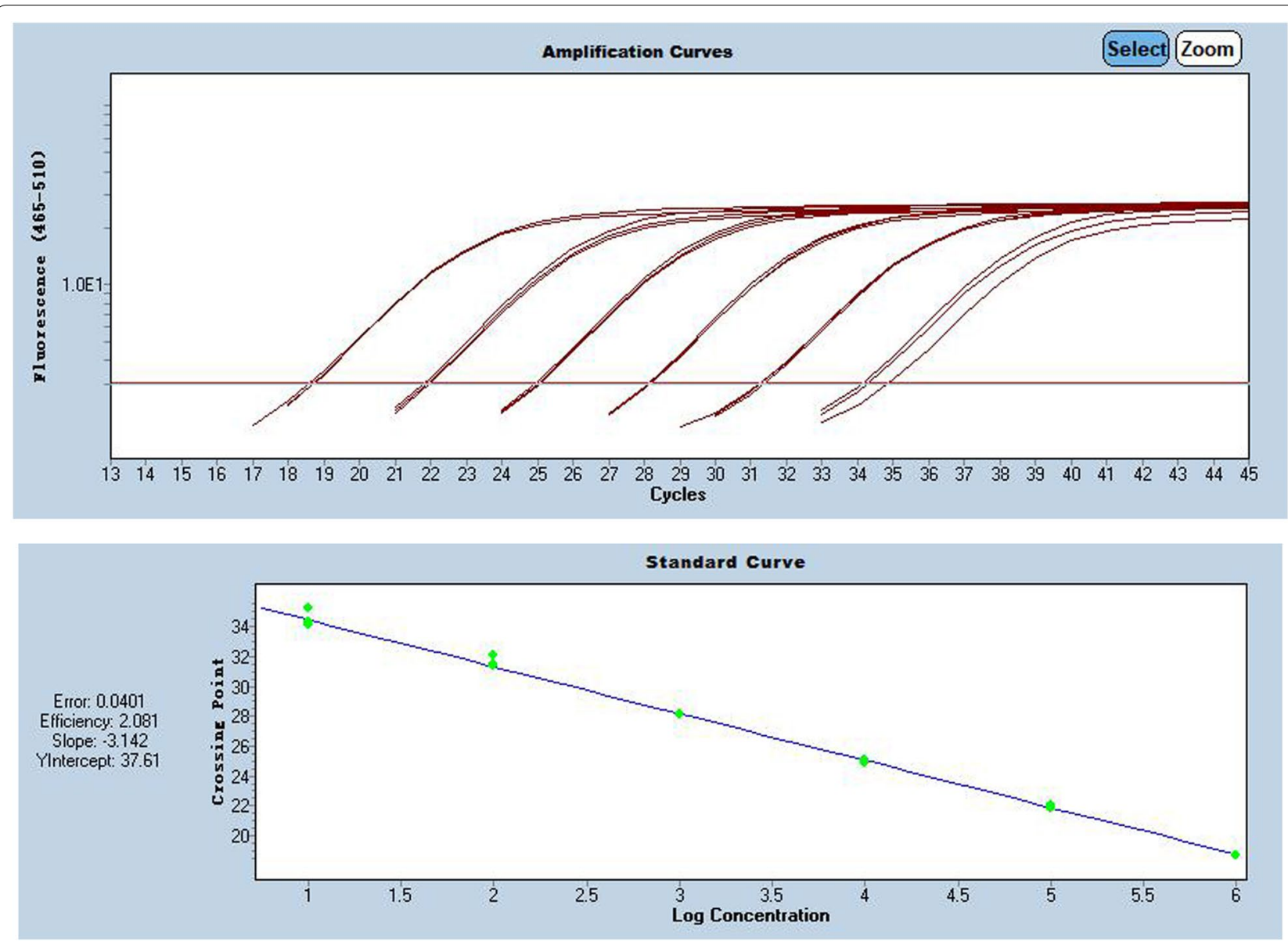

Fig. 1 Pre-experiment of E-gene amplification curve

$\operatorname{cobas}^{\circledR}$ Z480 RT-PCR system [12]. The sequence of forward primer is 5'-ACAGGTACGTTA ATAGTTAAT AGCGT-3' and the reverse primer is 5'-ATATTGCAG CAGTACGCACACA-3, targeting a 76-bp-long fragment from a conserved region in the $\mathrm{E}$ gene with FAM-labeled hydrolysis probes (530 channel) as FAM-ACACTAGCC ATCCTTACTGCGCTTCG-BBQ [5].

The assay was according to the kit instruction manual. Primers and probes of target gene and EAV (dry powders) were centrifuged for $2 \mathrm{~min}$ at $12000 \mathrm{rpm}$ and predissolved with $50 \mu \mathrm{L}$ PCR-grade water. Positive control of target gene RNA was centrifuged for $2 \mathrm{~min}$ at $12000 \mathrm{rpm}$ and pre-dissolved with $320 \mu \mathrm{l} 10 \mathrm{mM}$ Tris buffer. PCRgrade water is employed as negative control and tested from RNA extraction. One positive control and 3 negative controls were of minimal need for each test.

A $20-\mu \mathrm{L}$ reaction contained $10 \mu \mathrm{L}$ of $\mathrm{RNA}, 0.5 \mu \mathrm{L}$ of primer/probe premix, $0.5 \mu \mathrm{L}$ of EAV primer-probe premix, $4.0 \mu \mathrm{L}$ of RT-PCR Reaction Mix, $0.1 \mu \mathrm{L}$ of RTEnzyme Solution and $4.9 \mu \mathrm{L}$ of PCR-grade water. Thermal cycling was performed on Roche $\operatorname{cobas}^{\circledR} \mathrm{z} 480$ at
$55{ }^{\circ} \mathrm{C}$ for $5 \mathrm{~min}$ for reverse transcription, followed by $95^{\circ} \mathrm{C}$ for $5 \mathrm{~min}$ and then 45 cycles of $95^{\circ} \mathrm{C}$ for $5 \mathrm{~s}, 60^{\circ} \mathrm{C}$ for $15 \mathrm{~s}$ with single acquisition and $72{ }^{\circ} \mathrm{C}$ for $15 \mathrm{~s}$, followed by $30 \mathrm{~s}$ of $40^{\circ} \mathrm{C}$ for cooling down.

\section{Establishment of the standard curve}

The E-gene RNA single positive control (Tib-Molbiol, Germany. Product No. 30743771) contains 10E10 copies of RNA in one vial. 10E7 copies $/ \mu \mathrm{L}$ stock solution was obtained by dissolved one vial of E-gene RNA in $1000 \mu \mathrm{l}$ PCR-grade water. The stock solution was further dispensed into $15 \mu \mathrm{L} /$ tube and stored in PCR tubes at -18 to $20^{\circ} \mathrm{C}$ to avoid freezing and thawing.

Dilution rows were freshly prepared every day. One tube of stock solution was thawed and dilution rows from 10E6 to $10 \mathrm{E} 0$ copies/ $\mu \mathrm{L}$ was obtained by serial $1: 10$ dilution $(10 \mu \mathrm{L}$ of solution diluted with $90 \mu \mathrm{L}$ of PCR-grade water).

In each experiment, $10 \mu \mathrm{L}$ of each concentration of dilution rows (from 10E6 to $10 \mathrm{E} 0$ copies $/ \mu \mathrm{L}$ ) in a $20-\mu \mathrm{L}$ reaction was tested. Standard curve generated with the 

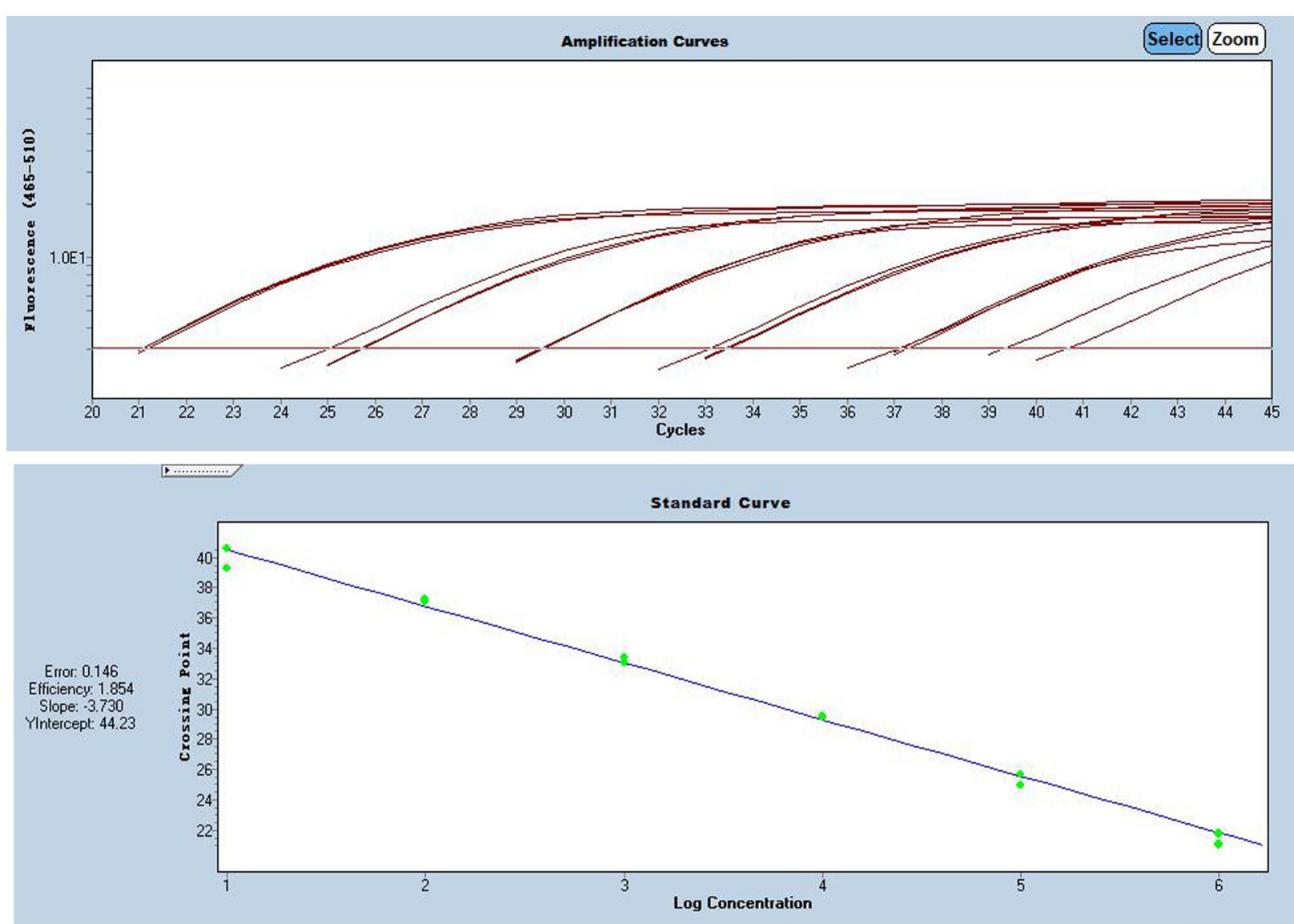

Fig. 2 Pre-experiment of $\mathrm{N}$-gene amplification curve

clinical sample together in each batch was used for viral load calculation.

\section{RNA extraction of clinical samples}

RNA was extracted from clinical samples using the MagNA Pure 96 system (Roche, Germany) with the High Pure Viral RNA Kit (Roche, Germany. Product No. 11858882001).

\section{Performance evaluation}

Limit of detection (LOD), lower limit of quantification (LLOQ) and inter/intra-run variability were evaluated. The limit of detection was determined by analyzing each of 20 replicates of $10 \mathrm{E} 1$ copies/ $\mu \mathrm{L}$ and $10 \mathrm{E} 0$ copies $/ \mu \mathrm{L}$ obtained from E-gene RNA dilution rows. The concentration at or above $95 \%$ detection probability is accepted as LOD. Lower limit of quantification (LLOQ) was determined by analyzing each of 6 replicates of dilution series from $10 \mathrm{E} 6$ to $10 \mathrm{E} 1$ copies $/ \mu \mathrm{L}$. The concentration at lower than $15 \%$ coefficient of variation $(\mathrm{CV})$ is considered as LLOQ. For estimation of inter/intra-run variability, we analyzed each of 5 positive samples and 5 negative samples confirmed by an EU CE certificated KingDIAN COVID-19 RT-PCR assay kit (DIAN Biotechnology. China) 3 times inter- and intra-run.

\section{Results}

Performance of the detection

No false positive or false negative results occurred in negative and positive controls in all tests. The cycle threshold (Ct) values of positive controls were between 29 and 31.

In the limit of detection (LOD) determination, for 20 replicates of $10 \mathrm{E} 1$ copies $/ \mu \mathrm{L}$, all of the replicates showed positive results with $\mathrm{Ct}$ values between 35.2 and 36.7. The coefficient of variation $(\mathrm{CV})$ is $1.03 \%$. For 20 replicates of $10 \mathrm{E} 0$ copies $/ \mu \mathrm{L}, 5$ showed undetected results. Therefore, we believe that the actual LOD of the test is between $10 \mathrm{E} 1$ and $10 \mathrm{E} 0$ copies/ $\mu \mathrm{L}$ and the confirmed LOD is $10 \mathrm{E} 1$ copies $/ \mu \mathrm{L}$.

For the lower limit of quantification (LLOQ) determination, the CV at $10 \mathrm{E} 2$ copies/ $\mu \mathrm{L}$ is $11.05 \%$ and $50.33 \%$ at $10 \mathrm{E} 1$ copies $/ \mu \mathrm{L}$. other $\mathrm{CV}$ values of higher concentration were $2.45 \%$ at $10 \mathrm{E} 6$ copies/ $\mu \mathrm{L}, 2.46 \%$ at $10 \mathrm{E} 5$ copies/ $\mu \mathrm{L}, 1.36 \%$ at $10 \mathrm{E} 4$ copies $/ \mu \mathrm{L}$ and $5.26 \%$ at $10 \mathrm{E} 3$ copies $/ \mu \mathrm{L}$. 

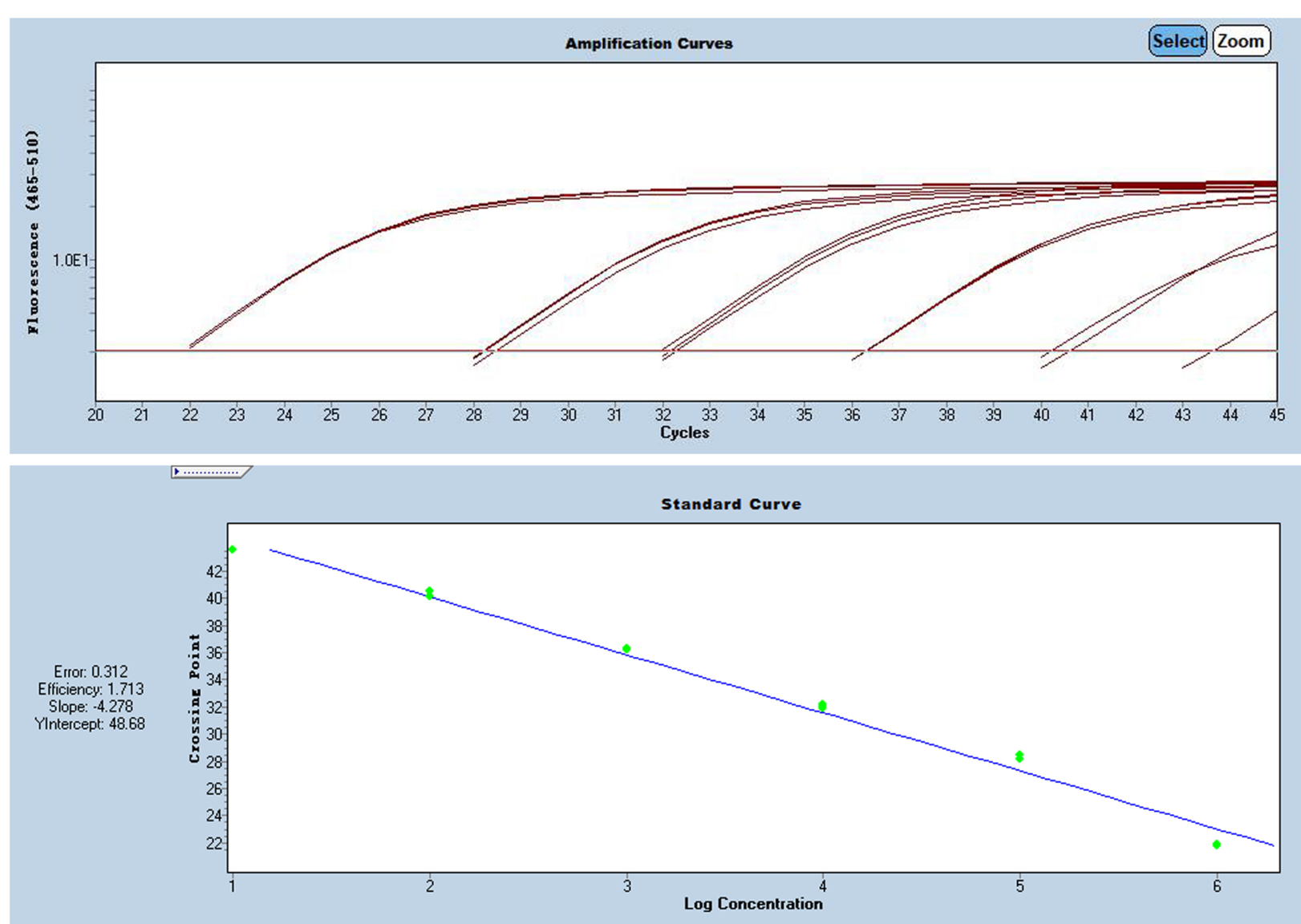

Fig. 3 Pre-experiment of RdRP-gene amplification curve

Those results provided an LLOQ of $10 \mathrm{E} 2$ copies/ $\mu \mathrm{L}$. So we chose dilution rows from 10E6 to $10 \mathrm{E} 2$ copies/ $\mu \mathrm{L}$ for the establishment of the standard curve in daily testing, as shown in Fig. 4.

For inter/intra-run variability, all CV values of 5 confirmed positive samples were below $15 \%$, all confirmed negative samples reported undetected.

\section{Discussion}

COVID-19 has become a high risk to the general population and healthcare workers worldwide. Facing the current situation that high infectivity and a large number of infected people, the development of accurate measurement and rapid detection methods is crucial. RT-PCR is widely deployed in the daily clinical assay of virus nucleic acid, which is of great importance for the diagnosis and monitoring of COVID-19. As viral load plays an essential part in diagnostic virology, we developed a quantitative RT-PCR method for COVID-19 virus detection in this study.

LightMix ${ }^{\circledR}$ Modular SARS-CoV (COVID19) E-gene kit was selected to develop the quantitative RT-PCR method. According to the description of the kit and previous report [10], this assay detects SARS and COVID-19 pneumonia virus as well as other batassociated SARS-related virus (Sarbecovirus), with no cross-reactivity with common human respiratory $\mathrm{CoV}$ NL63, 229E, HKU, OC43 or MERS. Since there is no evidence of the prevalence of SARS and other associated SARS-related viruses currently, we chose this kit for the establishment of quantitative detection of the COVID-19 virus.

Several researches have evaluated viral load by $\mathrm{Ct}$ values of RT-PCR [13]. However, due to the difference of amplification efficiency and the noise band adjustment, the $\mathrm{Ct}$ values of same sample could be significantly different in different tests, especially for low viral load samples. That's why the standard curve is deployed in most quantitative RT-PCR methods. In this study, we used dilution rows of an RNA standard to establish the standard curve, which enabled us to quantify viral RNA. The performance of the assay is acceptable with a limit of detection (LOD) below 10E1 copies/ $\mu \mathrm{L}$ and lower limit of quantification (LLOQ) as 10E2 copies/ $\mu \mathrm{L}$. 


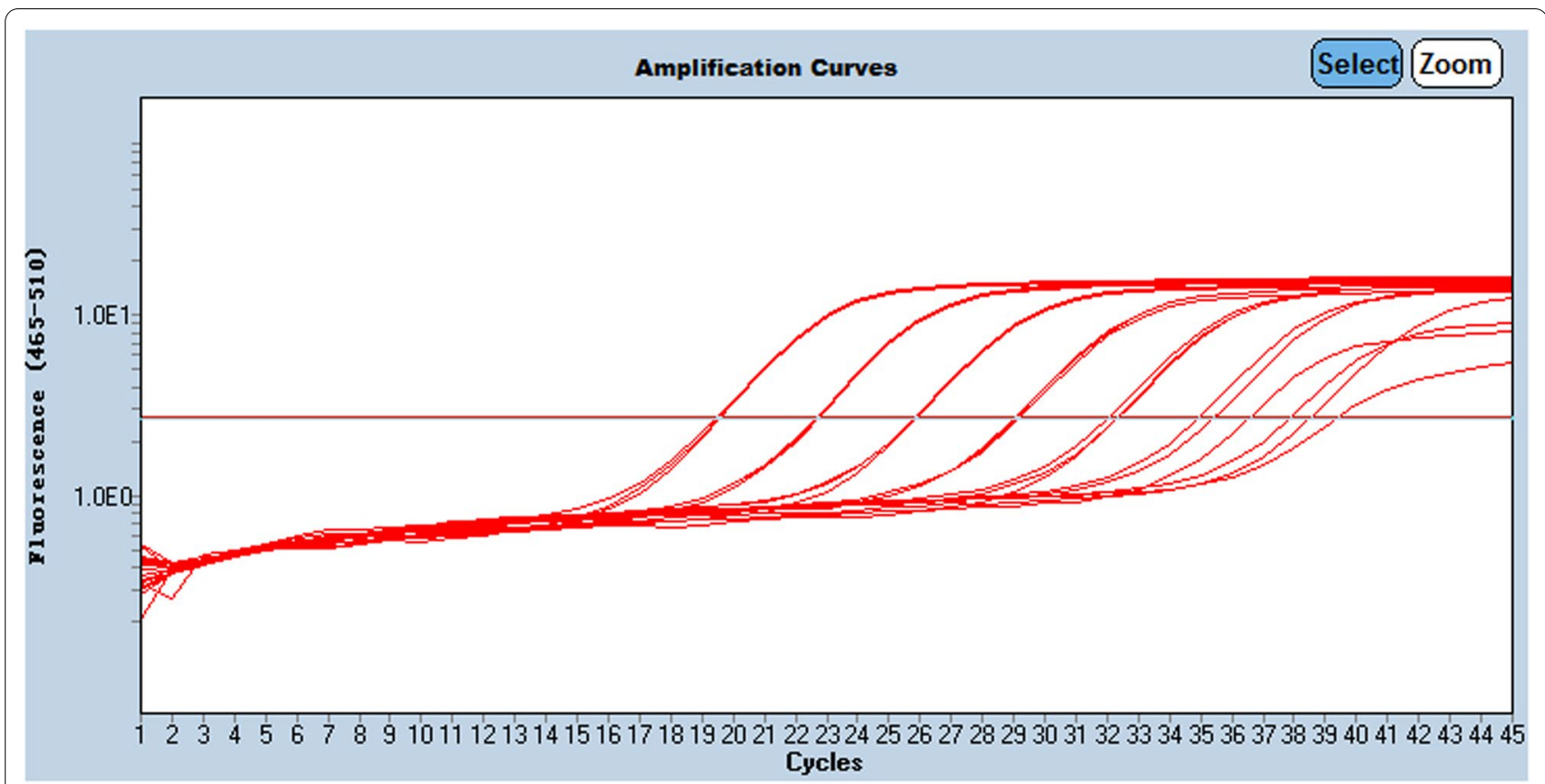

Fig. 4 Three replicates inter run of a dilution series from 10E6 to $10 \mathrm{E} 0$ copies/ $\mu \mathrm{L}$

There are still some limitations of this assay. The $\mathrm{E}$ gene RNA used to establish the standard curve is unstable in solution, especially at low concentration dilution. It could not be used for RNA extraction. Therefore, the viral loads reported by the assay could only reflect the viral loads in extracted RNA solution. Then, considering the current variant of SARS-CoV-2, such as B.1.351 Beta variant or GH501Y.V2 first detected in South Africa in October 2020, and the P.1 variant known as Gamma variant or GR/501Y.V3, which was identified in December 2020 in Brazil and was first detected in the US in January 2021, the detection effect of these mutated viruses will be evaluated in further study.

In summary, we established a quantitative detection method for the COVID-19 virus based on RT-PCR. This study provides a reference idea for the use of conventional qualitative detection PCR kits for quantitative detection, which can perform quantitative detection of new coronavirus nucleic acid at a lower cost level.

\section{Supplementary Information}

The online version contains supplementary material available at https://doi. org/10.1186/s40001-021-00608-5.

Additional file 1: Table S1. E-gene standard curve data summary.

\section{Authors' contributions}

Conception and design of the research:YSJ, SMZ. Acquisition of data:YSJ, $S M Z, H Q, S M, Y H S$. Analysis and interpretation of the data: YSJ, XYD, HL, XLX, GZZ. Statistical analysis: YSJ, YXL, BWC, YC, PL, HBH. Obtaining financing: none. Writing of the manuscript:YSJ, SMZ. Critical revision of the manuscript for intellectual content: YSJ. All authors read and approved the final manuscript.

\section{Funding}

None.

Availability of data and materials

The datasets used or analyzed during the current study are available from the corresponding author on reasonable request.

\section{Declarations}

\section{Ethics approval and consent to participate}

This study was conducted in accordance with the Declaration of Helsinki and approved by the ethics committee of our hospital.

\section{Consent for publication}

Not applicable.

\section{Competing interests}

All of the authors had no any personal, financial, commercial, or academic conflicts of interest separately.

\section{Author details}

${ }^{1}$ Rapid Diagnostics Laboratory, Hangzhou DIAN Medical Laboratories, No. 329 of Jinpeng Street, Xihu District, Hangzhou 310030, China. ${ }^{2}$ Teddy Clinical Research Laboratory (Shanghai) Limited, Shanghai 200433, China. ${ }^{3}$ Jiangxi DIAN-HUAXING Medical Laboratories, NanChang 330029, China. ${ }^{4}$ Tianjin DIAN Medical Laboratories, Tianjin 300300, China. ${ }^{5}$ WuHan DIAN Medical Laboratories, Wuhan 430034, China. 
Received: 13 July 2021 Accepted: 14 November 2021

Published online: 17 December 2021

\section{References}

1. Liu C, Shi Q, Peng M, Lu R, Li H, Cai Y, Chen J, Xu J, Shen B. Evaluation of droplet digital PCR for quantification of SARS-CoV-2 Virus in discharged COVID-19 patients. Aging (Albany NY). 2020;12(21):20997-1003.

2. Dong L, Zhou J, Niu C, Wang Q, Pan Y, Sheng S, Wang X, Zhang Y, Yang J, Liu M, Zhao Y, Zhang X, Zhu T, Peng T, Xie J, Gao Y, Wang D, Dai X, Fang $X$. Highly accurate and sensitive diagnostic detection of SARS-CoV-2 by digital PCR. Talanta. 2021;224:121726.

3. Huang D, Shi Z, Qian J, Bi K, Fang M, Xu Z. A CRISPR-Cas12a-derived biosensor enabling portable personal glucose meter readout for quantitative detection of SARS-CoV-2. Biotechnol Bioeng. 2021;118(4):1587-96.

4. Hung IF, Lau SK, Woo PC, Yuen KY. Viral loads in clinical specimens and SARS manifestations. Hong Kong Med J. 2009;15(Suppl 9):20-2.

5. Chu CM, Poon LL, Cheng VC, Chan KS, Hung IF, et al. Initial viral load and the outcomes of SARS. CMAJ. 2004;171:1349-52.

6. Han MS, Seong M-W, Kim N, Shin S, Cho SI, Park H, Kim TS, Park SS, Choi EH. Viral RNA load in mildly symptomatic and asymptomatic children with COVID-19. Seoul Emerg Infect Dis. 2020;26:2497-9.

7. Becker D, Sandoval E, Amin A, De Hoff P, Diets A, Leonetti N, Lim YW, Elliott C, Laurent LC, Grzymski J, et al. Saliva is less sensitive than nasopharyngeal swabs for COVID-19 detection in the community setting. medRxiv. 2020. https://doi.org/10.1101/2020.05.11.20092338.

8. Wölfel R, Corman VM, Guggemos W, Seilmaier M, Zange S, Müller MA Niemeyer D, Jones TC, Vollmar P, Rothe C, et al. Virological assessment of hospitalized patients with COVID-2019. Nature. 2020;581:465-9.

9. Cao B, Wang Y, Wen D, et al. A trial of lopinavir-ritonavir in adults hospitalized with severe covid-19. N Engl J Med. 2020;382(19):1787-99.

10. Wang Y, Zhang D, Du G, et al. Remdesivir in adults with severe COVID-19: a randomised, double-blind, placebo-controlled, multicentre trial. Lancet. 2020;395(10236):1569-78

11. Dong Y, Wu X, Li S, et al. Comparative evaluation of 19 reverse transcription loop-mediated isothermal amplification assays for detection of SARS-CoV-2. Sci Rep. 2021;11(1):2936.

12. Corman VM, Landt $O$, Kaiser M, et al. Detection of 2019 novel coronavirus (2019-nCoV) by real-time RT-PCR. Euro Surveill. 2020;25(3):2000045.

13. Zou L, Ruan F, Huang M, Liang L, Huang H, et al. SARS-CoV-2 viral load in upper respiratory specimens of infected patients. N Engl J Med. 2020;382:1177-9.

\section{Publisher's Note}

Springer Nature remains neutral with regard to jurisdictional claims in published maps and institutional affiliations.

Ready to submit your research? Choose BMC and benefit from:

- fast, convenient online submission

- thorough peer review by experienced researchers in your field

- rapid publication on acceptance

- support for research data, including large and complex data types

- gold Open Access which fosters wider collaboration and increased citations

- maximum visibility for your research: over $100 \mathrm{M}$ website views per year

At BMC, research is always in progress.

Learn more biomedcentral.com/submissions 